\title{
John Updike's Terrorist: Islamist Misogyny or a Backlash on American Feminist Propaganda?
}

\author{
Waleed Al-Galissy \\ School of Language, Literature \& Culture Studies, Swami Ramanand Teerth Marathwada \\ University, Nanded, India \\ Bhagwan S. Jadhav (Corresponding Author) \\ School of Language, Literature \& Culture Studies, Swami Ramanand Teerth Marathwada \\ University, Nanded, India \\ Email: bhagwansjadhav@srtmun.ac.in
}

Received: 10/07/2020

Accepted: 20/08/2020

Published: 01/09/2020

Volume: 1 Issue: 3

How to cite this paper: Al-Galissy, W. \& Jadhav, B. S. (2020). John Updike's Terrorist: Islamist Misogyny or a Backlash on American Feminist Propaganda? Journal of Critical Studies in Language and Literature, 1(3), 89-93

DOI: https://doi.org/10.46809/jcsll.v1i3.33

Copyright $@ 2020$ by author(s) and Global Talent Academy Ltd. This work is licensed under the Creative Commons Attribution International License (CC BY 4.0).

http://creativecommons.org/licenses/by/4.0/

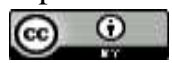

\begin{abstract}
The United States of America launched its war on terror in October, 2001. The war was declared both as a fight against terrorism and a mission to liberate the powerless, oppressed Muslim women. The Orientalist representation of Muslim women as a victim of their misogynistic culture is observed to have been re-invented by this twin rhetoric of war on terror of the American Government. Following the assumption that American literary artists would devote their artistic talent in support of their government, critics and scholars have excessively approached post 9/11 literature through Edward Said's theory of Orientalism. While it is true that some American artists represent the conflict to be between two civilizations (modern vs backward), but the theory affect has made it difficult to imagine a western literary depiction without an Orientalist lens. Consequently, western texts become vulnerable to misunderstanding or biased reading. John Updike's Terrorist (2006), for example, has been read as an Orientalist text in which women are used to depict Muslim frustration toward women liberation. Focusing on the representation of women, this article explores Updike's text as a backlash on American feminist politicized discourse, a new strategy of narrative to encounter the dominant narrative and challenge the tradition of Orientalism.
\end{abstract}

Keywords: Feminism, Orientalism, Misogyny, Women, Muslim

In response to the September 11, 2001 terrorist attacks, the United States of America-led coalition invaded Afghanistan with the aim of fighting the terrorist group al-Qaeda. But as the policy of Bush administration included the overthrow of the Taliban regime, the American media started mainstreaming Taliban's oppressive treatment of women. The State Department's report 'The Taliban's War against Women' detailed the degradation of women's rights and livelihoods under Taliban rule and called on Congress to pass the 'Afghan Women and Children Relief Act of 2001.' On November 17, 2001, U.S. first-lady Laura Bush and the U.S. State Department delivered a joint humanitarian call to action in the war to fight terrorism (Pacwa, 2019, p. 1). Laura Bush echoed the State Department's report and expressed similar sentiments: 
Civilized people throughout the world are speaking out in horror - not only because our hearts break for the women and children in Afghanistan, but also because in Afghanistan we see the world the terrorists would like to impose on the rest of us... And they must be stopped. The fight against terrorism is also a fight for the rights and dignity of women (as quoted in Hudson \& Leidl, 2015, p.38).

According to Hudson and Leidl (2015), Mrs. Bush confirmed in her speech that women's rights were preserved in the Islamic world, observing that Muslim women were significantly contributing in their society not like in Afghanistan (p. 38). Nevertheless, the U.S. administration put women at the centre again once it decided to invade Iraq, and the American media presented the Iraqi women to be living in the same situation of women in Afghanistan. It was effective in publicizing Saddam's misdeeds against women (Jabbra, 2006, p. 248).

The U.S government rhetoric and media coverage of women's status from Afghanistan to Iraq delivered a message that oppression of women was inherent in Islamic countries despite the different kind of regimes. The American invasions and occupations were represented as a mission to save and liberate Muslim terrorized and powerless women. This manipulation of feminism continued even after the invasion of Iraq. During the presidential election 2004, George W. Bush once said, "with the American power, young women across the middle East will hear the message that their day of equality and justice is coming" (as quoted in Wilson, 2005, p.140).

For political analysts, the U.S. government used the feminist language to manipulate the feminist population. It was an excellent way to sell its wars. Women's rights rhetoric reframed the military response to the events of 9/11 and the invasion of Iraq in a humanitarian terminology as a way to justify U.S. military presence in these countries. Cynthia Enloe points out that this discourse of Muslim women "has been taken off the nineteenth century imperial shelf, dusted, polished, and put to new use especially by officials of the US administration of Bush and their international allies in order to wrap its war in the justifying banner of women's liberation"(Hunt \& Rygiel, 2008, p. xi).

In effect, contemporary western literary artists, Americans in particular, are seen to have reconstructed the nineteenth century images of Muslim women as object of desire, elusive harem girls, and victims of their religious patriarchal culture. They have followed the tradition of orientalism, using Muslim women in their literary representation to establish a sense of imperial self-justification. They depict Muslim women as victims of their anachronistic faith, lacking agency and voice, and the Muslim male as an oppressor and terrorist. This, in turn, has necessitated the post 9/11 literature to be approached exorbitantly through Edward Said's theory of Orientalism and its extension neo-Orientalism. Almost all American literary post 9/11 projects are deemed to be mere fictionalization of the neo-Orientalist studies and analyses of Arab and Islam, producing ideological stereotype and biased representation.

Updike's Terrorist (2006) has been studied through neo-Orientalism. Some scholars argue that Updike represents patriarchy and misogyny as inflection of Islam. Through his Islamist would-be-terrorist character Ahmed, Updike is interpreted as depicting the Orientalist discourse of Islam. He uses women to show that Muslim persona suffer from identity crisis, frustrated with women emancipation; and thus, incompatible with modernity.

This article presents an analysis of the representation of women in Updike's Terrorist, showing that Updike's novel does not conform to the tradition of Orientalism. With reference to the earlier studies of the novel that assume Orientalist depiction, the article shows that Updike's work challenges the tradition and is not informed by the neo-Orientalist political, cultural and psychological writings. Rather than using women to portray incompatibility of a Muslim character in modern world, the article argues that Updike encounters the tradition of orientalism and challenges the American war to liberate Muslim women narrative by launching a backlash against American feminist propaganda. It explores the novel as a critique on American women, a new counter-narrative strategy to challenge the American official narrative of war to liberate Muslim women.

Updike's Terrorist narrates the journey of Ahmed Ashmawy to Islam and extremism. Ahmed is a teenager of crosscultural marriage between an Egyptian Muslim father and an Irish-American Christian mother. The journey started with Ahmed's search of a trace of his Arab father who had abandoned the family and returned to Egypt at the time when Ahmed's "memories were beginning" (Updike, 2006, p. 99). In his search for that trace, Ahmed decides to convert to Islam at the age of eleven. Instead of converting to traditional Islam, the boy happens to fall into the trap of the extremist doctrine of the religion, Wahhabi Islam. Ahmed falls under the sway of a Yemeni Wahhabi Sheikh named Rashid and the manipulation of a Lebanese nationalist called Charlie. The two Arabs guide Ahmed to accept the execution of a suicidal terrorist act.

Affected by the theory of Orientalism and its new extension neo-Orientalism, some readers and scholars read Ahmed's search for a father as a symbolism of patriarchy. For example, Deyab equates Ahmed's wish to find something about his father in Islam with Greg's neo-Orientalist explanation about why young Muslims join terrorist groups. He quotes Greg's statement which reads,

In Muslim societies which, in many cases have a patriarchal cultural tradition, young persons who see no clear path for their future, are likely to submit to patriarchal authoritarian image of God, often similar to the image they had of their father when they were children (Deyab, 2014, p. 234). 
Mohammed Deyab fails to realize that Ahmed does not live in a Muslim patriarchal country but in America, that Ahmed grew up with a feminist non-Muslim mother, and that the boy was not previously a Muslim. Thus, Deyab's Islamic position and knowledge of Orientalism affected his reading to the extent that his response to the text has turned to be more biased than any Orientalist depiction of Muslim ever. His reading, but not Updike's text, suggests Islam and its patriarchy to be genetically transmitted to Ahmed through his father.

Other responses to the novel equate Updike's child's search for a father with neo-Orientalist psychological and cultural analyses of Francis Fukuyama (1989), Bernard Lewis (1990) and Samuel Huntington (1993), whose main theses assume that Islamic fundamentalism is a result of the decline of Islamic civilization. Muslims, they assume, are experiencing an identity crisis as they have failed to create a new identity compatible with the process of Modernity. The desperate search of identity pushes Muslims to go back to history searching for a root and turn violent as an answer to their existential angst. Accordingly, Khamas (2013) reads Ahmad's search for a father as a symbolism representing a "root or a history, to support him against the unbearable lightness of his existence"(p. 358).

This reading, too, neglects the fact that Updike's Ahmed does not live in an Islamic society to suggest that he has felt the decline of his civilization. Even if he had lived in the Islamic society, he could not have felt the need to establish an identity since he was just a child at the age of eleven. For such a child of Ahmed's age, Islam is just like anything, say a photo, hoped to provide a trace of an absent Daddy. In fact, the issue of an absent father with a child searching for a trace of him is a common theme in Updike's literary works, through which he seeks to depict the social problem of family's dysfunction in America. For example, in his earlier work Of the Farm, Joey is searching for something of his absent father. So he requests “All I need is a hat of Daddy's"(Updike, 1965, p. 66). Similarly, Ahmed's mother guesses that "a boy needs a father" (Updike, 2006, p. 117).

The fact that Ahmed was not a Muslim but a new convert makes him so different to be equated with already Muslims assumed to be living in an identity crisis and feeling the need of re-Islamization. Ahmed even has no illusion about his father (Updike, 2006, p. 89), and Updike's anonymous narrator confirms that Ahmed's faith is not inherited from a father present to reinforce fidelity; it is rather a chosen faith, and he continues,

Ahmed was a native-born, and in his travel in New Jersey he takes interest less in its pockets of a diluted Middle East than in the American reality all around, a sprawling ferment for which he feels the mild pity owed a failed experiment (Updike, 2006, p. 117).

Based on the above assumed symbols in the novel, critics or scholars go on to provide illustrations of their Orientalist reading, focusing on Ahmed's attitudes toward modern American women which is revealed right from the opening pages of the novel. The novel opens with Ahmed being eighteen years old, having been through radical religious brainwash for seven years. The first two-page monologue reveals what Ahmed has come to consider evil from his religious world view. Part of that evil is girls in high school who, he observes, "sway and sneer and expose their soft bodies and alluring hair. Their bare bellies adorned with shining navel studs and low-down purple tattoos" (Updike, 2006, p. 3). For him, these girls are little whores, bad and fallen (Updike, 2006, pp. 16-18).

While this description of girls shows Ahmed to be really modeled by his fundamentalist doctrine of Islam, Updike reveals another effective stem through his portrait of Ahmed's modern mother, her sexual desire and philosophy of motherhood. Updike represents Teresa Mulloy, Ahmed's mother, as a free woman who can live economically independent, make her choice, and impose her family's name on her child - a symbolic of her broader social agency (feminism). She is a representative of the American new feminist women who do not like to pursue professions which embody the emotional role surrounding motherhood and meet patriarchal expectations. She is a nurse's aide, a female profession always associated with the compassion of mothering, but she "never really wanted to be a nurse" because "nurse's aides do what nurses used to do", she rather "like hands-on, deal with people right down there at the level of their real needs (Updike, 2006, p. 92).

This embodies her philosophy of motherhood. And as a mother, Teresa prioritizes her interests above the needs of her child. She cares for her son less than she does for her job, painting and above all her sexual affairs; as a result, her son feels he has never been essential to her (Updike, 2006, p. 293). She is used to bring lovers to the apartment to satisfy her sexual desire paying no attention to the feelings of her child, to whom every one of those lovers appears to be saying "she may be your mother but I fuck her", and this as well as the "valuing of sexual performance over all family ties", according to the anonymous narrator, "was American” (Updike, 2006, p. 168).

Unlike the school consular, Teresa does not look perturbed by her son's decision to become a truck driver instead of joining college and completing his education. And when Jack Levy, the school consular, expresses his worries about the threat her child may face, she does nothing to avert it. Instead, she shows interest in seducing Jack into her bed. And when Jack turns to speak about Ahmed again soon as they have finished the sexual intercourse, the anonymous narrator notices Teresa "answers warily, feeling the transition from whore to mother (Updike, 2006, p. 163), reinforcing this maternal inadequacy.

Ahmed finds the image of his mother in the school girls. He sees them as possible embodiment of his mother's inadequacy. Considering this vulnerability, he regretfully contemplates that these little whores are going to be mothers (Updike, 2006, p. 17). In verification of Ahmed's perception, the character Joryleen stands as a veritable symbol. Like other girls in school, she is predestined in Ahmed's mind to be "heading straight for Hell" (Updike, 2006, p. 63). And, in just a few 
months after graduation, she confirms "Ahmad's early paranoid and judgmental rumination on the sexual temptation and rampant immorality represented by American girls"(Alghamdi, 2015, p. 8). She becomes a living proof of Ahmed's perception of the social illness as she becomes a prostitute to financially support her boyfriend.

Apart from being depicted as a living proof, Jorlyeen has no choice. She cannot stop prostitution if her boyfriend Tylenol decides not to. When Ahmed says to her that Tylenol will not let her stop once she decides not to work as a prostitute in order to provide him with money, "she confesses the truth of this with her silence"(Updike, 2006, p. 224). Ahmed realizes that she needs help to be a free woman. So he decides to name her as his beneficiary though she is not his legitimate inheritor from the point of view of his religion. He decides the compensation of his suicidal terrorist act which would be given to his mother - the legal inheritor — be given to Jorlyeen so as to help her achieve freedom (Updike, 2006, p. 235). Ahmed turns to be a liberator though a terrorist.

In relation, Updike's representation of the Islamic veil disturbs the American narrative. Ashamed of his mother's sexuality, Ahmed says to his mother that "if there was one thing he wanted for his graduation it was his mother not looking like a whore" (Updike, 2006, p. 116). The only gift he wants from his mother is just to put on veil as she attends the graduation party. From Ahmed's religious standpoint, the garment would hide his mother's sexual attractiveness and make her look decent. Yet, Levy finds the garment stirring. To him, Teresa looks more attractive with the headscarf on her head than without it. It "poses provocation, implying a dazzling ultimate nakedness. Her head scarf speaks of submission, which stirs him"(Updike, 2006, pp. 116-117). Hence, contrary to the western past Orientalist as well as the American recent discourse, Updike represents the Islamic veil as something that adds to the feminine beauty. He provides a different meaning of the garment from the one present in the consciousness of American feminist population. His depiction of the headscarf does not conform to the American government's rhetoric that Muslim women in veil are necessary oppressed and waiting the American hero to arrive and liberate them. It does not speak of the negative submission to patriarchy; rather it speaks of a submission that can drift a man at the age of sixties, like Levy, toward women.

In addition, Updike provides another critique on feminism through his portrait of the female character Hermione Fogel, the undersecretary in Department of Homeland Security. He represents her as a symbol of women who decide to pursue a career, but come to realize that their clock is running out to start a family. She feels jealous when her boss comes to mention his children. She thinks "they should be her children" for one reason that they together spend twelve, fourteen hours a day in the same room or adjacent rooms, they are just as much one as if legally married" (ibid 259). Seeing him upset for losing an asset, Hermione,

longs to comfort the Secretary, to press her lean body like a poultice upon his ache of overwhelming responsibility; she wants to take his meaty weight, which strains against his de rigueur black suit, upon her bony frame, and cradle him on her pelvis (Updike, 2006, p. 260).

Hermione is represented as spinster who has come to impose herself in her boss's life as a second female. She illustrates Mona Charen's statement in her article 'The Feminist Mistake' that while women have gained control of their fertility and have pursued their own professional dreams, women movement "has effectively robbed us of one thing upon which the happiness of most Women rests-men"(as cited in Faludi, 1991, p. 2). Furthermore, this also explains Ahmed's father's abandonment of the family. Men in America are seen to be falling away from their family responsibilities. Some socialists consider this decline of men as fathers and husbands in America as an unfortunate consequence of feminism. According to Chambers (2012), the U.S. ex- President Obama said on the Father's Day 2009,

If we are honest with ourselves, we'll admit that too many fathers are missing... missing from too many lives and too many homes. They have abandoned their responsibilities. They are acting like boys instead of men. And the foundations of our families are weakening because of it (p. 177).

Furthermore, Updike explores misogyny to be existent in the minds of both his Arab character Omar Ashmawy, Ahmed's father, and of American people. But when he represents Omar's misogynist tendency, he disassociates Islam. Teresa noticed Omar to be a Muslim only in name not in practice. She had tried to urge him to go to mosque and do his prayers, but

He'd clam up, and look sore, as if I was pushing in where I had no business. A woman should serve a man, not try to own him, he'd say, as if he were quoting some kind of Holy Writ. He'd made it up (Updike, 2006, p. 86).

The phrases as if he were... made it up clearly disassociate Islam from Omar's conviction that a woman is to serve a man. Misogyny in U.S. is revealed through Teresa's way of producing her paintings to people. She adopts the male artist name Terry instead of her own female name Teresa to sign them. "because female artists have always seemed smaller than the male ones, no matter how big they painted" (Updike, 2006, p. 86). This proves that even in the twenty-first century women artists are not treated at par with male artists in America.

To sum up, Updike's portrait is a backlash on American feminist propaganda. All women in the novel are depicted as losers. The modern mother is inadequate; the spinster feels her disillusion with feminism and is jealous of those who have children; the young can be vulnerable to forced prostitution. In this, Updike ridicules the American government's discourse 
of war to liberate veiled women, suggesting that the U.S government had better fight for women forced to prostitution domestically than going abroad to fight for women forced to wear headscarves. As such, the novel encounters Orientalism, old and new. It is a counter-narrative to the American government's discourse of war to emancipate Muslim women in so far as it is a critique on American women itself.

\section{References}

Alghamdi, A. (2015). Terrorism as a Gendered Familial Psychodrama in John Updike’s Terrorist. Moderna Språk, 109(1), 112.

Chambers, D. (2012). A Sociology of Family Life. Polity.

Deyab, M. S. (2014). Muslim Stereotypes in John Updike's Terrorist. In A. R. Richards \& I. Omidvar (Eds.), Muslims and American Popular Culture, 2, 219-238

Faludi, S. (1991). Backlash: The Undeclared War Against American Women. Three Rivers Press. https://doi.org/10.1177/036168439201600304

Hudson, V., \& Leidl, P. (2015). The Hillary Doctrine: Sex \& American Foreign Policy. Columbia University Press. https://doi.org/10.5860/choice.193151

Hunt, K., \& Rygiel, K. (2008). (En)Gendering the War on Terror: War Stories and Camouflaged Politics. Ashgate Publishing Limited.

Jabbra, N. W. (2006). Women, Words and War: Explaining 9/11 and Justifying U.S. Military action in Afghanistan and Iraq. Journal of International Women's Studies, 8(1), 236-255.

Khamas, E. A. (2013). New Colonial Rescue: Appropriating a Feminist Discourse in the War on Terror. Universitat Autònoma de Barcelona.

Pacwa, J. (2019). War on Terror as a "Fight for the Rights and Dignity of Women": a Discourse Analysis of the U.S. 'Liberation' Campaign for Afghan Women. https://digitalcommons.pepperdine.edu/etd/1101\%0A\%0A

Updike, J. (1965). Of The Farm. Ballantine Books.

Updike, J. (2006). Terrorist. Random House, Inc.

Wilson, B. (2005). Warshod: Living Victoriously in the End Times. Xulon Press. 